\title{
Indicators for Cultural and Creative Industries' Impact Assessment on Cultural Heritage and Tourism
}

\author{
Daniela Angelina Jelinčić
}

Citation: Jelinčić, D.A. Indicators for Cultural and Creative Industries' Impact Assessment on Cultural Heritage and Tourism. Sustainability 2021, 13, 7732. https://doi.org/ $10.3390 /$ su13147732

Academic Editors: Bart Neuts, João Martins, Milada Št' astná and John Martin

Received: 11 June 2021

Accepted: 9 July 2021

Published: 11 July 2021

Publisher's Note: MDPI stays neutral with regard to jurisdictional claims in published maps and institutional affiliations.

Institute for Development and International Relations, 10000 Zagreb, Croatia; daniela@irmo.hr

\begin{abstract}
Cultural heritage is an important factor in ensuring regional development. Practice has demonstrated that first sustainability of heritage sites needs to be ensured and tourism they generate should also be re-visited as current over-tourism models are unsustainable. The assumption is that cultural/creative industries (CCI) can be a powerful tool for heritage livability as well as for sustainable tourism based on experiences. In order to stimulate regional development, specific CCI measures are often introduced in public policies but results of policy interventions are rarely monitored. Their performance can be measured against the pre-set indicators. Research studies focusing on such indicators are scarce. This short communication provides a possible conceptual framework alongside concrete indicators for cultural/creative industries' sector impact assessment on cultural heritage and sustainable experiential tourism on the policy as well as on the project level. Desk research and brainstorming methods were applied to design the indicator sets resulting in a tool which is to be further tested and used in practice.
\end{abstract}

Keywords: cultural heritage; cultural/creative industries; experience tourism; impact assessment; indicators

Cultural heritage has an important role in sustainable development and regional resilience. It ensures employment, impacts tourism development and entrepreneurship consequently influencing increased income for the local population as well as tax revenues for the government. Further on, its role in ensuring social sustainability is seen in the social cohesion, inclusion, participation and local community well-being [1,2]. It may equally ensure environmental sustainability in promoting greener economy and climate adaptation as well as cultural sustainability since heritage is often featured in literature, films, music and visual arts. Its educational and scientific role is also immense as heritage is often used in (in)formal education or is a subject of various research.

It is estimated that "cultural tourism accounts for $40 \%$ of all European tourism; 4 out of 10 tourists choose their destination based on its cultural offering" [3], and "it is safe to assume that majority of tourist attractions and destinations in the world today are based on elements of cultural heritage" [4] (p. 3). This fact usually looks promising for cultural heritage managers since cultural tourism greatly contributes to the financial sustainability of heritage sites and to regional development. In practice, however, not all heritage sites are equally valorized. Some of them are subject to over-visitation, while others are totally deprived from visitors. Dual situation is noted:

1. For a long time a number of heritage interventions have been abundantly funded from different EU sources but failed to ensure sustainability, among other, due to the missing audiences; and

2. Tourism, although primarily contributing to heritage financial sustainability and regional economic sustainability, has become the very threat to it as over-tourism moves center-stage for some heritage sites.

Therefore, one of the main challenges in ensuring cultural heritage sustainability is its adequate management, which relates to integrated management process, from heritage 
product development to its interpretation. Cultural/creative industries proved to be effective on that task as they offer livability; heritage is not and should not be a static symbol of the past but is a living proof of a community identity related to their contemporary ways of living. Using architecture, arts, design, film, music, etc. may greatly enhance heritage attractiveness for the local community and visitors, thus having a direct relation with heritage audience development. On the other hand, the pre-pandemic over-tourism requires re-modelling by offering individual experiences. Cultural/creative industries again have a say in it since they offer tools for experience design.

The main assumption is, therefore, that ensuring heritage sustainability by the use of cultural/creative industries consequently also impacts development of sustainable experiential tourism and is in direct relationship with regional resilience and sustainable development.

In order to ensure heritage sustainability and ensure its impact on economy, society, environment and culture, it is necessary to develop adequate public policies, which can justify their investments in cultural heritage and stimulate development of sustainable tourism. Such policies need regular monitoring and evaluation, which is rarely performed in practice, checking their performance against the pre-set indicators. There are scarce research studies focusing on cultural heritage sustainability indicators, e.g., [5,6] and those relating to indicators to be used in decision-making are especially uncommon, e.g., [2].

This short communication provides a possible conceptual framework alongside concrete indicators for cultural/creative industries' sector impact assessment on cultural heritage and sustainable experiential tourism. They have been developed based on the Jelinčić and Tišma's study [5] which introduced measurement of heritage sustainability by three sets of indicators: sociocultural (covering 12 areas), environmental ( 3 areas) and economic sustainability ( 7 areas). As much as their work is well grounded, and areas well determined, the indicator sets are not all encompassing but only mentioned on the level of examples. This short communication aims to fill this gap by offering an all-encompassing indicator sets and introducing cultural/creative industries as one of the drivers for heritage sustainability. With this aim, methodology used by the Cultural and Creative Cities Monitor (CCCM) [7] has been consulted and some of the indicator areas introduced and further developed. The work has also been complemented with desk research. Different studies have been consulted focusing on creativity indexes, e.g., [8,9], cultural citizenship indexes [10], heritage sustainability indexes [11] and tourism sustainability indicators [12,13]. Based on that, indicators for cultural/creative industries' impact assessment on cultural heritage are proposed on two levels: policy level and project level. At the policy level, they potentially serve decision-makers against which policy interventions can be measured and adequately adapted, while on the project level, they serve cultural heritage managers in their daily operations potentially leading to a successful management of their cultural heritage sites.

The proposed indicator sets for cultural/creative industries' impact assessment on cultural heritage on the policy level are divided in three main heritage areas: heritage vibrancy, creative economy and enabling environment following the CCCM methodology. Each of them is further divided in specific heritage themes, and for each of them indicators proposed (see Table 1). Public policies may consider the introduction of the proposed indicators while introducing specific measures to stimulate sustainable heritage projects.

On the project level, more specific and detailed indicators may be introduced to ensure sustainability of a specific heritage site. Thus, nine heritage areas are proposed in line with the usual cultural heritage management concept (see Table 2). These allow performance management measurement at the level of a specific heritage site and may be a useful tool in daily operations. 
Table 1. Indicators for CCIs' impact assessment on cultural heritage on the policy level.

\begin{tabular}{|c|c|c|}
\hline Heritage Area & Heritage Theme & Indicators \\
\hline \multirow[b]{2}{*}{ Heritage vibrancy } & Heritage attractions & $\begin{array}{l}\text { - Number of heritage attractions using CCIs in } \\
\text { different aspects of cultural heritage management } \\
\text { - Number of CCIs used for achieving heritage } \\
\text { vibrancy }\end{array}$ \\
\hline & Heritage participation and attractiveness & $\begin{array}{l}\text { - Number of visitors to heritage sites } \\
\text { - } \quad \text { Lumber of programs organized at heritage sites } \\
\text { heritage in marketing campaigns, photo } \\
\text { shootings, filmmaking, etc.) }\end{array}$ \\
\hline \multirow{3}{*}{ Creative economy } & Creative and knowledge-based jobs & $\begin{array}{l}\text { - Number of creative and knowledge-based jobs in } \\
\text { the heritage sector } \\
\text { - Number of new creative and knowledge-based } \\
\text { jobs in the heritage sector }\end{array}$ \\
\hline & Heritage innovation & $\begin{array}{l}\text { Number of CCI-related innovations in the } \\
\text { heritage sector } \\
\text { Number of CCI-related patents in the heritage } \\
\text { sector }\end{array}$ \\
\hline & Internationalization of heritage & $\begin{array}{l}\text { - International branding of national heritage } \\
\text { - } \quad \text { Number of international visitors to heritage sites }\end{array}$ \\
\hline \multirow{2}{*}{ Enabling environment } & Human capital and heritage education & $\begin{array}{l}\text { - CCIs' use in enhancing the human capital on } \\
\text { heritage } \\
\text { - } \quad \text { Number of heritage-related educational } \\
\text { programs based on CCIs } \\
\text { Number of educated persons }\end{array}$ \\
\hline & Quality management of heritage & $\begin{array}{l}\text { - Availability of quality heritage management } \\
\text { educational programs/trainings } \\
\text { - } \quad \text { Skilled cultural heritage workers } \\
\text { - Overall level of heritage preservation and its } \\
\text { cultural/environmental/financial/social } \\
\text { sustainability }\end{array}$ \\
\hline
\end{tabular}

As cultural/creative industries are also important tools for experience design, they have an important role in experiential tourism which is considered to be sustainable as it focuses on needs and desires of individual tourists, thus avoiding masses and overtourism. This may be especially important for tourism policies, which before the pandemic hardly coped with over-tourism. The proposed indicators for CCIs' impact assessment on sustainable experiential tourism on the policy level are divided in two main tourism areas: tourism sustainability, and tourism experiences. These are further developed in specific tourism themes with associated indicators (see Table 3.) 
Table 2. Indicators for CCIs' impact assessment on cultural heritage on the project level.

\begin{tabular}{|c|c|c|}
\hline Heritage Area & Heritage Theme & Indicators \\
\hline \multirow{3}{*}{$\begin{array}{c}\text { Heritage preservation and protection } \\
\text { enhancement }\end{array}$} & Research & $\begin{array}{l}\text { - Number of research activities using CCIs } \\
\text { Number of CCIs used for heritage research } \\
\text { activities }\end{array}$ \\
\hline & Preservation & $\begin{array}{l}\text { - Number of heritage-related } \\
\text { traditions/customs/knowledge preserved } \\
\text { Existence of CCI-related systems for heritage } \\
\text { preservation } \\
\text { Level of heritage preservation after the } \\
\text { application of CCI-related heritage } \\
\text { preservation systems }\end{array}$ \\
\hline & Protection & $\begin{array}{l}\text { Existence of CCI-related systems for heritage } \\
\text { protection } \\
\text { Level of heritage preservation after the } \\
\text { application of CCI-related heritage protection } \\
\text { systems } \\
\text { Existence of technological solutions to decrease } \\
\text { social (e.g., over-visitation, looting) or natural } \\
\text { pressures (e.g., earthquakes, volcano eruptions, } \\
\text { floods, invasive plants, carbon emission, } \\
\text { climate change) }\end{array}$ \\
\hline
\end{tabular}

- Number of heritage visitors due to CCI intervention into heritage

Revival - Number of aesthetic CCI interventions into heritage sites for urban/rural territorial development

Heritage revival and livability

Livability
- Number of enhanced heritage-related services due to CCI intervention (e.g., technology-based educational tours, digitization for scientific purposes)

- Number of CCI products promoting a heritage brand
Financial, environmental and socio-cultural sustainability of cultural heritage
Financial sustainability
- Number of CCI-related funding sources (e.g., crowdfunding, CCI products retail, co-branding, CCI-related interpretation)

- Amount of CCI-related funds earned

- Number of CCI entrepreneurs/enterprises using heritage infrastructure, equipment and interpretation tools in their business operations (e.g., for advertising, filmmaking, video-clips and music recordings, space rentals, etc.) 
Table 2. Cont.

$\begin{array}{lll}\text { Heritage Area } & \text { Heritage Theme } & \text { Indicators }\end{array}$

- Number of activities of heritage digitization

Environmental sustainability

- $\quad$ Existence of CCI-related systems for environmental protection

- $\quad$ Existence of CCI-related systems for monitoring activities

Socio-cultural sustainability

- Number of research projects related to heritage

- Number of researchers participating in heritage-related research activities

- Number of published papers, master's and doctoral dissertations related to heritage

- Number of CCI-related educational and awareness raising programs on heritage

- Number of educated participants in topics related to heritage

- Number of CCI programs/activities at a heritage site

- Number of participants in CCI programs/activities

- Cultural heritage presence in artworks, stories, films, music compositions, design, etc.

- Number of artists and CCI workers using heritage infrastructure for cultural creation

- Number of new/enhanced CCI

Heritage products/services enhancement

Products/services products/services related to $\mathrm{CH}$ (e.g., films, books, designs, musical pieces, etc.)

- Number of companies with new heritage-related CCI products

- Number of new/enhanced CCI-related

Distribution

Pricing/sales

Heritage marketingimprovement product/services distribution channels

- $\quad$ Number of CCI-related products/services sold/used
Branding
- Number of heritage-based unique selling points in collaboration with CCI

- Number of CCI products promoting a heritage brand 
Table 2. Cont.

\begin{tabular}{|c|c|c|}
\hline Heritage Area & Heritage Theme & Indicators \\
\hline \multirow{3}{*}{ Heritage interpretation enhancement } & Interpretive media & $\begin{array}{l}\text { - Number of innovative interpretation media } \\
\text { using CCIs (e.g., QR codes, 3D technologies, } \\
\text { multimedia and interactive tools, multisensory } \\
\text { media, enhanced interpretive design, } \\
\text { interpretive films, etc.) } \\
\text { - Number of new storytellers }\end{array}$ \\
\hline & Visitor satisfaction & $\begin{array}{l}\text { - Number of satisfied heritage visitors due to the } \\
\text { introduction of CCI-related interpretive media }\end{array}$ \\
\hline & $\begin{array}{l}\text { Heritage awareness and } \\
\text { education }\end{array}$ & $\begin{array}{l}\text { - Level of heritage interpretation } \\
\text { understanding/raised awareness due to the } \\
\text { introduction of CCI-related interpretive media }\end{array}$ \\
\hline \multirow{2}{*}{$\begin{array}{l}\text { Enhanced human resources } \\
\text { management }\end{array}$} & Employees & $\begin{array}{l}\text { Use of CCI-related human resources } \\
\text { management tools (e.g., software) } \\
\text { Level of effectiveness of CCI-related human } \\
\text { resources management tools } \\
\text { - Number of new CCI-related job openings }\end{array}$ \\
\hline & Volunteers & $\begin{array}{l}\text { - Use of CCIs in volunteer engagement } \\
\text { - Number of CCI-related volunteering programs } \\
\text { applied }\end{array}$ \\
\hline
\end{tabular}

- Number of uses of CCIs for smart visitor management design (e.g., design, film,

Tools architecture, publishing, ICT, etc.)

- $\quad$ Existence of CCI-related visitor management tools (e.g., visitor counting systems)

Visitor management improvement

Visitor number and satisfaction
- Increase and level of satisfaction of heritage visitors due to CCI-related visitor management tools

- $\quad$ Share of heritage visitors compared to other selected and relevant heritage attractions

- Number of CCIs used in audience development

- Existence of an innovative CCI-related entrance counting system
Local community

Access 
Table 2. Cont.

Heritage Area Heritage Theme

Indicators

- $\quad$ Number of CCI-related outreaching methods to involve local community

- Number of people/groups involved

- Number of local community members participating in CCI heritage-related activities (e.g., music festivals, book readings,

Participation exhibitions, film shows, etc.)

- Number of local community members offered the opportunity to distribute their CCI-related products/services at a heritage site

- Number of local community members' CCI-related products/services offered at a heritage site

Table 3. Indicators for CCIs' impact assessment on sustainable experiential tourism on the policy level.

Tourism sustainability

Tourism Theme

Financial and economic sustainability of CCI-related tourism programs

Environmental sustainability

Socio-cultural sustainability
- Number of operational CCI entrepreneurs/enterprises working in tourism in a 5-year span

- Number of tourists in CCI-related programs/activities

- $\quad$ Existence of CCI-related systems for environmental protection in tourism infrastructure

- $\quad$ Existence of technological solutions to decrease over-visitation and natural pressures impacting tourism

- $\quad$ Existence of CCI-related educational and awareness raising programs on sustainable tourism

- Number of educated participants in topics related to tourism

- Number of artworks, stories, films, music compositions, design, etc. used as a basis for tourism programs

- Number of CCIs used in the construction/enhancement of tourism buildings (e.g., architecture, design, music, visual arts, ICT, etc.)

\section{Tourism experiences}

Tourism infrastructure improvement
- Number of local CCI SMEs/start-ups engaged in the construction/enhancement of tourism buildings 
Table 3. Cont.

Tourism Area $\quad$ Tourism Theme

Indicators

- Number of new/enhanced CCI products/services related to tourism (e.g., films, books, designs, musical pieces, creative gastronomy, cultural tourism routes, experiences, etc.)

Experiential tourism products/services

- Number of tourists participating in/consuming CCI tourism-related activities (e.g., music festivals, exhibitions, performing arts shows, cultural tourism routes etc.)

Marketing and market development

- Number of CCI-related experiential tourism products/services sold/used

- Use of CCIs in experiential branding and market reach

Finally, indicators for CCIs' impact assessment on sustainable experiential tourism on the project level are proposed (Table 4). They are divided in eight main tourism areas, touching main issues in tourism project management. As with the previous sets, this is also further elaborated in specific themes and indicators.

Table 4. Indicators for CCIs' impact assessment on sustainable experiential tourism on the project level.

\begin{tabular}{|c|c|c|}
\hline Tourism Area & Tourism Theme & Indicators \\
\hline \multirow{2}{*}{$\begin{array}{l}\text { Financial, social, environmental and } \\
\text { cultural sustainability of tourism } \\
\text { projects }\end{array}$} & Financial sustainability & $\begin{array}{l}\text { Number of operational CCI } \\
\text { entrepreneurs/enterprises working } \\
\text { in tourism in a 5-year span } \\
\text { Increase in CCI SMEs and start-ups } \\
\text { income in a 5-year span } \\
\text { - } \quad \text { Number of CCI-related funding } \\
\text { sources (e.g., crowdfunding, CCI } \\
\text { products retail, co-branding, } \\
\text { CCI-related interpretation) for } \\
\text { tourism programs } \\
\text { Amount of CCI-related funds } \\
\text { earned } \\
\text { Number of tourism programs using } \\
\text { CCI-related programs/activities } \\
\text { Number of tourists in CCI-related } \\
\text { programs/activities }\end{array}$ \\
\hline & Environmental sustainability & $\begin{array}{l}\text { Existence of CCI-related systems for } \\
\text { environmental protection in tourism } \\
\text { infrastructure } \\
\text { - } \begin{array}{l}\text { Existence of CCI-related systems for } \\
\text { monitoring activities }\end{array} \\
\text { Existence of technological solutions } \\
\text { to decrease over-visitation and natu- } \\
\text { ral pressures impacting tourism }\end{array}$ \\
\hline
\end{tabular}


Table 4. Cont.

Tourism Area Tourism Theme

Socio-cultural sustainability

Physical infrastructure
Technical infrastructure

\section{Indicators}

- Number of research projects related to tourism

- Number of researchers participating in tourism-related research activities

- Number of published papers, master's and doctoral dissertations related to tourism

- $\quad$ Number of CCI-related educational and awareness raising programs on tourism

- Number of educated participants in topics related to tourism

- CCI presence in artworks, stories, films, music compositions, design, etc. used as a basis for tourism programs

- Number of tourism buildings using local architects' design

- Number of CCIs used in the construction/enhancement of tourism buildings (e.g., architecture, design, music, visual arts, ICT, etc.)

- Number of local CCI SMEs/start-ups engaged in the construction/enhancement of tourism buildings

\section{Tourism infrastructure improvement}

- Number of technology-related enhancements of tourism products/services (e.g., IoT-based hotel services, experiences, multisensory products, etc.)

- Number of tourism workers trained in topics related to contemporary tourism trends (e.g., experiential tourism, creative tourism, transformative tourism, etc.)

Tourism products/services enhancement
Human capacity building
- Number of training activities in topics related to contemporary tourism trends (e.g., experiential tourism, creative tourism, transformative tourism, etc.) 
Table 4. Cont.

- Number of new/enhanced CCI products/services related to tourism (e.g., films, books, designs, musical pieces, creative gastronomy, cultural tourism routes, experiences, etc.)

New products/services

Distribution

Pricing/sales

Tourism marketing improvement
- Number of tourism services using technology (e.g., IoT, experiences, technology-based educational tours etc.)

- Number of tourists participating in/consuming CCI tourism-related activities (e.g., music festivals, exhibitions, performing arts shows, cultural tourism routes etc.)

- Number of new/enhanced CCI-related product/services distribution channels

- $\quad$ Existence of an innovative CCI-related tourism ticketing system

- Number of CCI-related tourism products/services sold/used

Number of CCIs used in tourism brand design

Branding

- $\quad$ Number of CCI products promoting a tourism brand

- Number of new/enhanced tourism promotional campaigns using CCIs

Promotion

- Number of communication channels used

- Number of media engaged

- Number of CCIs used in new tourist markets reach and development

- $\quad$ Number of CCI-related outreaching

New markets reach methods towards new markets

- Number of young tourists using CCI-related tourism products/services

\section{Market/visitor development}

- Percentage of satisfied tourists due to consumption of CCI-related products/services

Tourist satisfaction and loyalty
- Share of satisfied tourists compared to other selected and relevant tourism attractions 
Table 4. Cont.

Tourism Area $\quad$ Tourism Theme

Indicators

- Number of tourism workers trained

Education and training for sustainable experiential tourism

Enhanced human resources management in experiential tourism (e.g., topics: theming, positive and negative cues in experience design, experiential souvenirs, engagement of the senses, emotional branding, etc.)

- Use of CCI-related human resources management tools in tourism (e.g., software)

Employees

- $\quad$ Level of effectiveness of CCI-related human resources management tools in tourism

- $\quad$ Number of new CCI-related tourism job openings
Tools

Tourists management improvement
- $\quad$ Number of uses of CCIs for smart visitor management design (e.g., design, film, architecture, publishing, ICT, etc.)

- Existence of CCI-related visitor management tools (e.g., tourists counting systems)

- Increase and level of satisfaction of tourism visitors due to CCI-related visitor management tools

- $\quad$ Share of tourists compared to other selected and relevant tourist attractions
Local community and interaction with tourists
Participation

- $\quad$ Number of CCI-related outreaching methods to involve local community in decision-making on tourism development/management

- Number of people/groups involved

- Number of local community members offered the opportunity to distribute their CCI-related tourism products/services

- Number of local community members' CCI-related tourism products/services offered 
Table 4. Cont.

Tourism Area Tourism Theme

Interaction

Complexity of issues to be regarded in the heritage/tourism management posed to be a challenge in the design of these indicator sets. First, there are a lot of sustainability issues to be taken into account which results in a number of indicators. Second, there are overlapping issues which can be treated from different perspectives (e.g., local community management can be seen from the point of view of social sustainability or economic sustainability). This may be considered as a limitation to this conceptual framework. The fact is that the integrated indicator sets are rarely available and they have to be adapted to a specific situation.

The proposed conceptual framework and indicator sets are to be further tested. Then, the ex post analyses should be made as to measure their relevance, effectiveness and efficiency. Their contribution is primarily seen in the facilitation of the monitoring process, and consequently in matching the performance of the measures/activities against the policy instrument priorities or project goals. Based on this, policy instruments as well as individual heritage/tourism projects may be enhanced.

Funding: This specific research received no external funding but has resulted based on experience gained through several projects funded by Interreg Europe (KEEP ON), Interreg Central Europe (ForHeritage) and Interreg VB Adriatic-Ionian / Regional Development Agency Dubrovnik-Neretva County DUNEA (CREATURES). The APC was funded by the Institute for Development and International Relations.

Institutional Review Board Statement: Not applicable.

Informed Consent Statement: Not applicable.

Data Availability Statement: Not applicable.

Conflicts of Interest: The author declares no conflict of interest.

\section{References}

1. United Nations. Draft Outcome Document of the United Nations Conference on Housing and Sustainable Urban Development (Habitat III); United Nations: New York, NY, USA, 2016.

2. Nocca, F. The role of cultural heritage in sustainable development: Multidimensional indicators as decision-making tool. Sustainability 2017, 9, 1882. [CrossRef]

3. European Commission. Cultural Tourism. Available online: https://ec.europa.eu/growth/sectors/tourism/offer/cultural_en (accessed on 7 June 2021).

4. Timothy, D.J. Cultural Heritage and Tourism: An Introduction; Channel View Publications: Bristol, Uk; Tonawanda, NY, USA; North York, ON, Canada, 2011.

5. Jelinčić, D.A.; Tišma, S. Ensuring sustainability of cultural heritage through effective public policies. Urbani Izziv/Urban Chall. 2020, 31, 78-87. [CrossRef]

6. Vecco, M.; Srakar, A. The unbearable sustainability of cultural heritage: An attempt to create an index of cultural heritage sustainability in conflict and war regions. J. Cult. Herit. 2018, 33, 293-302. [CrossRef] 
7. European Commission. Cultural and Creative Cities Monitor. Available online: https:/ / composite-indicators.jrc.ec.europa.eu/ cultural-creative-cities-monitor (accessed on 8 June 2021).

8. Rodrigues, M.; Franco, M. Composite index to measure cities' creative performance: An empirical study in the Portuguese context. Sustainability 2019, 11, 774. [CrossRef]

9. Montalto, V.; Tacao Moura, C.J.; Langedijk, S.; Saisana, M. Culture counts: An empirical approach to measure the cultural and creative vitality of European cities. Cities 2019, 89, 167-185. [CrossRef]

10. Mercer, C. Towards Cultural Citizenship: Tools for Cultural Policy and Development; The Bank of Sweden Tercentenary Foundation \& Gidlunds Förlag: Södertälje, Sweden, 2002; Available online: https:/ /www.academia.edu/786688/Towards_Cultural_ Citizenship_Tools_for_Cultural_Policy_and_Development (accessed on 11 June 2021).

11. Ren, W.; Han, F. Indicators for assessing the sustainability of built heritage attractions: An Anglo-Chinese study. Sustainability 2018, 10, 2504. [CrossRef]

12. UNWTO. What Tourism Managers Need to Know: A Practical Guide to the Development and Use of Indicators of Sustainable Tourism; UNWTO: Madrid, Spain, 1996.

13. World Tourism Organization. Indicators of Sustainable Development for Tourism Destinations; UNWTO: Madrid, Spain, 2004. 